\title{
Additions to the Sponge Fauna at Plymouth.
}

\author{
By \\ M. Burton, M.Sc., \\ Assistant Keeper, Department of Zoology, British Museum (Natural History), London.
}

With 9 Figures in the Text.

During a short visit to Plymouth, in 1928, Dr. M. W. de Laubenfels made a collection of sponges which, with the exception of six, he identified and deposited in the Biological Laboratory at Plymouth. Before leaving England he left these six with me, with the request that they should be identified. This I have now done, and the results have proved extremely interesting, adding six species, Halichondria bowerbanki, Mycale similaris, Iophon hyndmani, Endectyon delaubenfelsi, Hymedesmia stephensi, and Pachaxinella subdola, to the recorded faunal list for Plymouth, of which three are new species.

\section{HALICHONDRIA BOWERBANKI sp. n.}

Spongia coalita Lamouroux 1816, p. 80 ; Lamarck 1816, p. 382 ; Grant 1825, pp. 95, 96, 101, 102, 105, 340 ; Id. 1826 a pp. 114, 116-118, 120, 338 ; Id. $1826 \xi$, p. 347 ; Id. $1826 \eta$, pp. $123,135$.

Halichondria coalita Fleming 1828, p. 522; Bellamy 1839, p. 268; Johnston 1842, p. 135, pl. xii, fig. 1; Bowerbank 1866, p. 238 ; Parfitt 1868 , p. 11.

Amorphina coalita Schmidt 1870, p. 77.

Halichondria coalita Bowerbank 1874, p. 102, pl. xli, figs. 18-20 ; Id. 1882, p. 96.

Halichondria panicea (pars) Levinsen $1887 \alpha$, p. 512.

Amorphina coalita Topsent 1888, p. 146.

Halichondria coalita Topsent 1911 $\alpha$, pp. i-xv ; Id. 1913, p. 31.

Diagnosis.--Sponge typically repent, and sub-ramose or profusely branched; branches frequently anastomosing; surface smooth, slightly uneven ; texture compact, friable ; oscules small, few, or not apparent ; colour, in life, yellowish, dried, white; oxea ranging from $\cdot 2$ by $\cdot 003$ to $\cdot 33$ by $\cdot 012 \mathrm{~mm}$.

(There is little to choose between this species and Halichondria panicea. The main differences are that in $H$. bowerbanki the external form is usually ramose, the oscules are inconspicuous, the dermal reticulation more 
strongly marked, and the oxea slightly stouter. Topsent (1911 $\alpha$ ) has also shown a difference in the larvæ of the two species.)

Remarks.-The species coalita, usually ascribed to Bowerbank or Johnston, is first mentioned by Müller (1776), but between the date of its inception and the year in which Johnston gave it an adequate description and illustration, its history is a series of errors and confusions. Müller appears to have taken as his type the specimen figured by Ellis (1755, p. 80 , pl. xxxii, fig. F ; not p. 95 , as quoted by Müller), which is almost certainly a slightly atypical, though fairly common, form of Chalinc oculata, and to which Ellis gave the name of Spongia ramosa Britannica. Thirteen years later Müller (1789) once again refers to Spongia coalita, this time giving his own figure, that of a white encrusting sponge growing on a branching Cœlenterate. It is impossible to tell what this sponge was, but it was most probably a specimen of Halichondria panicea. Gmelin (1791, p. 3825) described Spongia coalita as "Sp. ramosissima mollis tenera flava, ramis compressiusculis. Habitat in mari norwegico." This helps very little, but since Gmelin probably took his ideas from Müller, we may justifiably regard it as a synonym of Chalina oculata. In the same way, Bosc (1802, p. 146), in describing the species as "Très-rameuse, molle, tendre, jaune; les rameaux applatis," was probably following Müller's first description, and we may regard his sponge as Chalina oculata. Turton (1806, p. 662) appears to have merely translated Bosc's description when he says, "Very much branched, soft, tender, yellow, the branches a little compressed."

Lamouroux (1816), on the other hand, appears to have had before him a sponge similar to that which Johnston and Bowerbank both figure as Halichondria coalita. He says " "bảse étalée en membrane qui enveloppe plusieurs corps et qui se divise en rameaux prolifères, mous, doux au toucher ; surface irregulièrement réticulée." At the same time, even this is open to doubt. He quotes Spongia Lycopodium Esper as a synonym, which is quite wrong. Lamarck (1816), who appears to be slavishly following Lamouroux, even to the extent of quoting S. Lycopodium as a synonym, describes S. coalita as " Sp. basi dilatata, corpora aliena obvolvens, ramosissima ; ramis tereticompressis, ramulosis; superficie fibris apressis."

Montagu (1818, p. 80) gives as his diagnosis of $S$. coalita, "much branched in an irregular and distorted manner, rather compressed and of brittle corky substance," a description aptly fitting Chalina oculata when dried. Gray (1821, p. 355) in describing his "Coalescent Tuphe," uses almost the same words as Montagu, but treats the sponge as an alga.

Grant, from whose papers Johnston quoted extensively in his description. of Halichondria coalita, and Fleming (1828, p. 522), were evidently dealing with the sponge Bowerbank (1874) so clearly figured. Fleming gives as 
his diagnosis, "growth very irregular, branches more or less compressed, frequently uniting; substance resembling $H$. papillaris (which we now know to be a synonym of $H$. panicea) ; tubular processes sometimes occur on the sides of the branches, with small round orifices. It grows on dead shells or invests corallines, beyond low-water mark." Bellamy, in recording the sponge from South Devon, merely remarks that it is "not uncommon on exposed beaches." His sponge is, therefore, clearly not Chalina oculata, but is probably Halichondria coalita or H. panicea.

Blainville (1834, p. 532) merely quotes Müller.

After this date, following the accounts given by Johnston and Bowerbank, the conception of $H$. coalita becomes quite clear and consistent.

Prior to Johnston, therefore, we can divide the references to the species into three groups; those probably synonymous with Chalina oculata, with Halichondria panicea, and with another species which I shall call H. bowerbanki sp. n., as follows :-

\section{Chalina oculata.}

Spongia coalita Müller 1776, p. 256.

Spongia coalita Gmelin 1791, p. 3825.

Spongia coalita Bosc 1802, p. 146.

Spongia coalita Turton 1806, p. 662.

Spongia coalita Montagu 1818, p. 80.

Tupha coalita Gray 1821, p. 355.

Spongia coalita Blainville 1834, p. 532.

\section{Halichondria panicea.}

Spongia coalita Müller 1789, p. 71, pl. 120.

Halichondria coalita Bellamy 1839, p. 268.

Halichondria bowerbanki sp. n. with synonymy as given at the beginning. Since Bowerbank's specimen is the only one which has survived, and of which we can have first-hand knowledge, I take this for the holotype of the new species.

Distribution.--Arctic Seas; Norway; British Isles; France.

\section{Mycale similaris (Bowerbank).}

(See Topsent 1924, p. 109.)

Remarks.-I have re-examined the holotype of Raphiodesma fallaciosum Bowerbank and find, as Topsent (l.c., p. 84) tentatively suggests, that it is a synonym of Mycale similaris.

Distribution.-Jersey; Westport, Ireland; France, North and East coasts. 


\section{IOPHON HYNDMANI (Bowerbank).}

Remarks.-As I hope shortly to publish a comprehensive study of the Iophoneæ generally, it is inadvisable to say more concerning this species now.

Distribution.-British Isles generally and, probably, along the whole of the Atlantic coast of Europe.

\section{genus Endectyon Topsent.}

Genotype.-Phakellia tenax Schmidt.

Diagnosis.-Ectyoninæ of erect, branching habit; branches supported by an axial skeleton composed of a uni- or multispicular reticulation of smooth styli, which may be partially or wholly replaced by acanthostyli ; surface of sponge rendered hispid by projecting brushes of long smooth styli, with which a third category of spicule, slender styli, may be associated.

\section{Endectyon delaubenfelsi sp. $\mathrm{n}$.}

(Text figs. 1, 2, 3.)

Holotype.-B.M. 29.8.21.3.

Diagnosis.-Sponge erect, stipitate, branched, composed of a number of irregular branches lying in one plane; surface coarsely hispid; oscules and pores not apparent; colour, in life, golden-yellow ; skeleton composed of an axial reticulation of small styli and acanthostyli, which gives off short bundles of spicules on its outer fringes to run vertically to dermis; surface echinated by bundles of long styli; spicules:-(i) long smooth styli, usually straight, almost entirely confined to surface brushes, $\cdot 85$ by $\cdot 007$ to $\cdot 012 \mathrm{~mm}$. ; (ii) short styli, smooth, usually curved, often vermiform, roughly divisible into two categories, $\cdot 18$ by $\cdot 005 \mathrm{~mm}$. and $\cdot 225$ by $.005 \mathrm{~mm}$.; (iii) acanthostyli, sparingly beset with spines which occasionally form a crown at either base or apex of spicule, $\cdot 18$ by $\cdot 006$; microscleres absent.

Remarks.-The species is interesting from many points of view. In the first place, new species of sponges are rarely found in British waters to-day, and it is extremely likely that this one has been overlooked hitherto owing to its extremely close resemblance to Raspaitia ventilabrum (Bowerbank). Indeed, from external appearance only it is quite impossible to tell the two species apart. This emphasizes, once again, the great need for examining all sponges microscopically in order to be absolutely certain as to their identity.

The present species is the third one recorded for the genus Endectyon, the other two, E. tenax and E. demonstrans, having been found off Florida and the Azores respectively (see Topsent $1920 \beta$, pp. 23-26).

The chief interest attaching to it, however, is that the spiculation shows 
the manner in which the acanthostyli of the Ectyoninæ may have arisen. The axial skeleton of the branches consists of a multispicular reticulation of triangular meshes, built up of small styli, for the
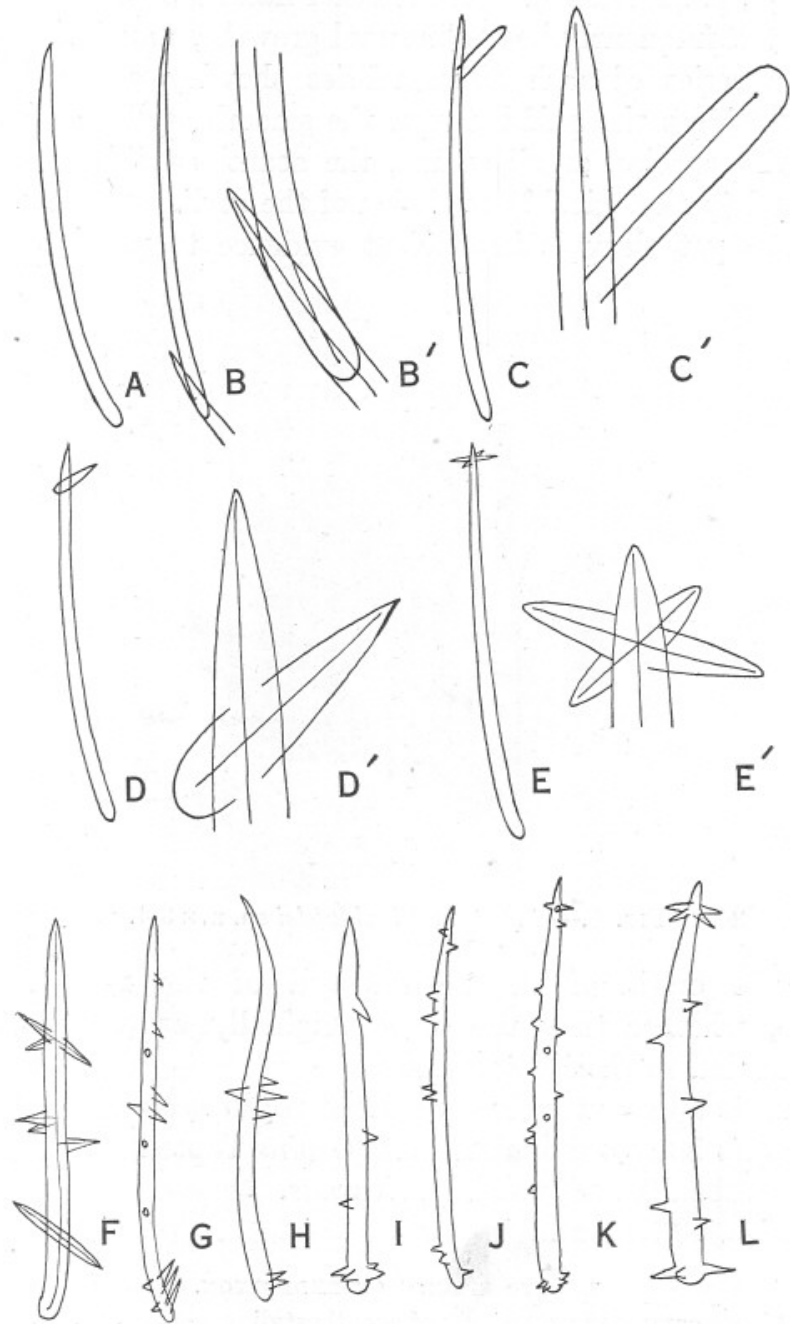

FIG. 1.-Endectyon delaubenfelsi sp.n. A. Normal stylus of main skeleton; B-E. abnormal styli ( $\mathrm{B}^{\prime}-\mathrm{E}^{\prime}$. abnormalities enlarged) ; F-H. abnormal styli showing transitions to normal acanthostyli; I-L. normal acanthostyli. All figures (except $\left.\mathrm{B}^{\prime}-\mathrm{E}^{\prime}\right) \times 220$.

most part curved, and acanthostyli. The latter, however, are of comparatively rare occurrence. The typical form (figs. $1 \mathrm{I}, \mathrm{L}$.) is that of a smooth style bearing a few stout spines. In a few cases, the NEW SERIES.-VOL. XVI. No. 2. MARCH, 1930. 
spines have become so grouped that the spicule is ornamented by „crowns of spines, four to six in number, at either end of the spicule. In this condition the spicules closely resemble those of the genotype, E. tenax (see Topsent, l.c., p. 24, fig. 4b). On the other hand, the smooth styli of the axial skeleton frequently bear abnormal growths, and it is possible to pick out a series of such abnormalities showing a transition which effectually bridges the gulf between the smooth styli and the acanthostyli. In this species, at all events, the acanthostyli have arisen from an abnormal (pathological ?) condition of the styli. The next question, for which as yet there is insufficient evidence to provide an answer,

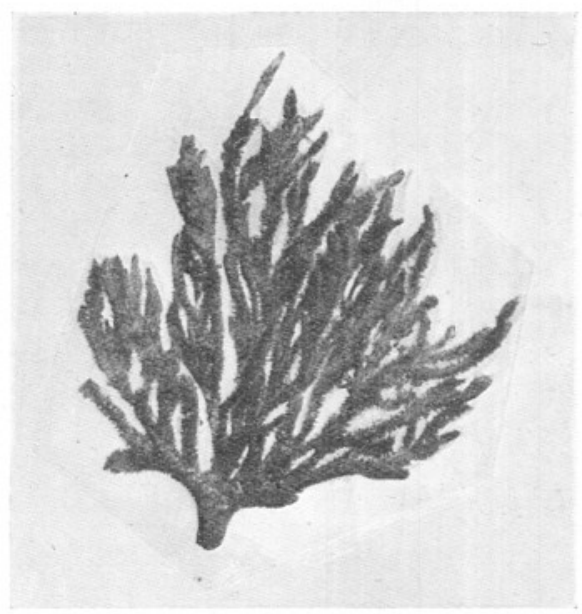

Fra. 2.-Endectyon delaubenfelsi sp. $\mathrm{n} . \times 3 / 4$.

concerns the origin of the acanthostyli of the remainder of the Ectyoninæ, whether they too arose originally as abnormalities and what factors led to their stabilisation.

Endectyon is apparently closely related to Hemectyon Topsent (genotype Raspailia hamata Schmidt), Tethyospira Topsent (genotype Tethea spinosa Bowerbank), and, possibly, Acarnus.

Distribution.-Plymouth.

KEY TO SPECIES OF ENDECTYON.

$1\{$ Axial skeleton composed exclusively of acanthostyli . . . . . demonstrans $\left\{\begin{array}{l}\text { Axial skeleton composed of a mixture of smooth styli and acanthostyli } \\ \text {. }\end{array}\right.$

$2\{$ Acanthostyli invariably with a crown of recurved spines at each end . . . tenax $\{$ Acanthostyli only occasionally bearing a crown of spines at either end . delaubenfelsi

HyMedesmia stephensi sp. $\mathrm{n}$.

(Fig. 4.)

Holotype.-B.M. 29.8.21.5.

Diagnosis.-Sponge thinly encrusting; surface uneven, minutely 
hispid, in places slightly conulose; oscules few, scattered, conspicuous ; pores not apparent; colour, in life, brown ; texture, in life, "slimy" ; megascleres of main skeleton divided into two categories, long acanthostyli, usually slightly curved, sparingly spined and often quite smooth, .225 by $.007 \mathrm{~mm}$., and small entirely spined acanthostyli, $\cdot 048$ by $\cdot 002$ $\mathrm{mm}$.; tornota very variable in shape, straight, smooth, with hastate mucronate, strongylote, or slightly tylote heads, $\cdot 165$ by $\cdot 003 \mathrm{~mm}$.

Remarks.-The species finds its closest ally in $H$. mucronella Lundbeck, from which it differs in many important respects, notably in the size and

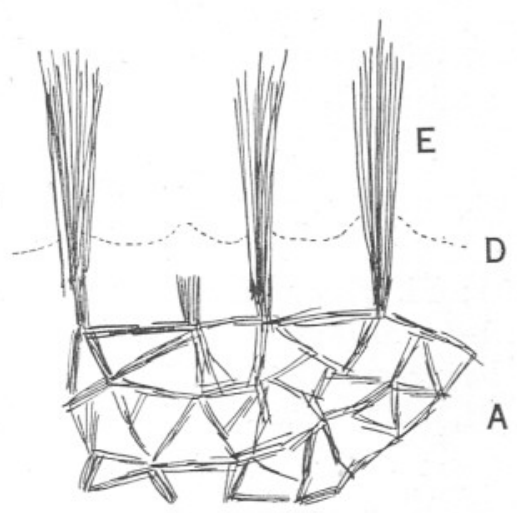

Fia. 3.-Endectyon delaubenfelsi sp. n. Section at right angles to surface, showing, A, reticulation of styli and acanthostyli of internal skeleton; $\mathrm{D}$, dermis ; and E, echinating tufts of long styli at the surface. (Diagram. matic.)

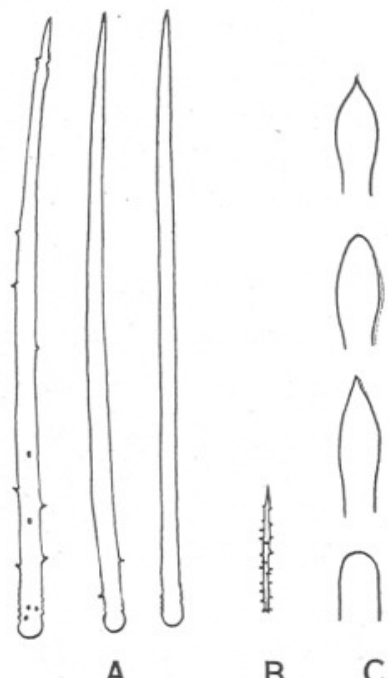

Frg. 4.-Hymedesmia stephensi $\mathrm{sp}$. n.

A, styli of main skeleton, $\times 260$; $\mathrm{B}$, acanthostyle, $\times 260$; C, heads of tornota, to show variability in form, $\times 2600$.

shape of the acanthostyli and the variability of the ends of the tornota. The small size of the smaller acanthostyli is, indeed, its characteristic feature.

Dr. de Laubenfels describes this sponge in life as " brown, slimy."

Distribution.-Plymouth.

List of species of Hymedesmia recorded for the British Isles.

The following list of 21 species of Hymedesmia represents the complete list recorded for the British Isles. So far, the only species recorded for the Plymouth area is $H$. stephensi sp. n., but since there is no obvious reason why they may not all be found there, in time, I have 
thought it worth while to give this list. Several of the British species described by Bowerbank have hitherto been only inadequately described. The re-descriptions given here are based on a re-examination of the types.

GeNus Hymedesmia Bowerbank.

Genotype.-H. zetlandica Bowerbank.

Diagnosis.-Ectyoninæ of encrusting habit; main skeleton composed of acanthostyli, of one or more kinds, variable in size, placed vertically with their bases echinating the substratum; dermal skeleton composed of tornota variously disposed, either in bundles running vertically from the apices of the acanthostyli to the surface, in scattered bundles, or in a horizontal layer supporting the dermis ; microscleres chelæ, occasionally absent, and/or sigmata.

\section{H. zetLandica Bowerbank.}

H. zetlandica Bowerbank 1864, p. 190 ; Id. 1866, p. 152 ; Gray 1867, p. 537 ; Id. 1874, p. 73, pl. xxix, figs. 1-7; Myxilla zetlandica Vosmaer 1880 , p. 126 ; Hymedesmia zetlandica Bowerbank 1882, p. 70 ; Topsent 1888, p. 142 ; Leptosia zetlandica Id. 1894, p. 31 ; Hymedesmia zetlandica Stephens 1921, p. 32, pl. iv, fig. 3.

Distribution.--Shetland Is.; S.W. coast of Ireland.

\section{H. RADIATA Bowerbank.}

H. radiata Bowerbank 1866, p. 149 ; Epicles radiatus Gray 1867, p. 521 ; Hymedesmia radiata Bowerbank 1874, p. 71, pl. xxviii, figs. 1-4, pl. xxix, fig. 8 ; Id. 1882, p. 56 ; Myxilla radiata Topsent 1892, p. 109 ; Hymeraphia radiata Hanitsch 1894, p. 196 ; Dendy 1921, 84.

Diagnosis.-Megascleres of main skeleton divided into two categories, long, smooth styli, usually straight or nearly so, sometimes slightly subtylostylote, up to 1.8 by $.012 \mathrm{~mm}$., and entirely spined acanthostyli, with somewhat pronounced head, from $\cdot 075$ by $\cdot 004$ to $\cdot 24$ by $\cdot 009 \mathrm{~mm}$.; tornota, sometimes inclined to be slightly vermiform, arranged for most part in stellate groups in dermis, with strongylote ends, $\cdot 27$ by $.003 \mathrm{~mm}$.

Remarks. - The specimen described by Dendy under this name evidently represents a totally different species which I propose to call Hymedesmia dendyi sp. n. The suggestion made by Dendy, that Topsent's Myxilla radiata differs specifically from Hymedesmia radiata, is almost certainly wrong.

Distribution.-Shetland Is., and the Minch, Scotland; Azores. 
3. H. Paupertas (Bowerbank).

Hymeniacidon paupertas Bowerbank 1866, p. 223 ; Id. 1874, p. 93, pl. xxxvii, figs. 4-8; Myxilla paupertas Vosmaer 1880, p. 127 ; Hymeniacidon paupertas Bowerbank 1882, p. 92 ; Myxilla paupertas Ridley and Dendy 1887, p. 143 ; Hymeraphia paupertas Hanitsch 1894, p. 177 ; Topsent $1894 \beta$, p. 18; Hymedesmia paupertas Stephens 1912, p. 28 ; Id. 1921, p. 31, pl. iv, fig. 1:

Remarks.-Contrary to the assertion of Ridley and Dendy (l.c.), Bowerbank's preparations show that the species is, quite unmistakably, a Hymedesmia. Myxilla paupertas Topsent (1904, p. 168) is obviously different to Bowerbank's species and, since it is almost certainly a true Myxilla, I propose for it the name $M$. topsenti sp. n.

Distribution.-Greenland; Shetland Is. ; W. and S.W. coasts of Ireland.

\section{H. BRONDSTEDI sp. n.}

Hymeniacidon dujardinii Bowerbank 1866, p. 224 ; Id. 1874, p. 95, pl. xxxviii, figs. 1-4; Id. 1882, p. 92 ; Stylopus dujardini Levinsen $1887 \alpha$, p. 512 ; Dendoryx dujardini Topsent 1888, p. 146 ; Id. 1890, p. 201 ; Id. 1891, p. 528 ; Id. 1892, p. 99 ; Myxilla radiata Id. l.c., p. 109 ; Leptosia dujardini Id. $1894 \alpha$, p. 37 ; Id. $1896 \beta$, p. 275 ; Id. $1902 \beta$, p. 353 ; Id. $1904 a$, p. 185, pl. i, fig. 5 ; Hymedesmia dujardinii Lundbeck 1909, p. 444 ; Id. 1910, p. 101, pl. x, fig. 5 ; Hymedesmia dujardini Arndt 1912, p. 119 ; Stephens 1917, p. 11 ; Id. 1921, p. 40.

Remarks.-In describing his Hymeniacidon dujardinii, Bowerbank was under the impression that it was specifically identical with Johnson's Halisarca dujardinii. Since this is clearly a case of wrong identification, the name dujardinii as applied to Hymeniacidon and, since Bowerbank's time, to Hymedesmia, cannot stand. I propose, therefore, the name brondstedi.

Distribution.-N.E., S.E., and W. coasts of Ireland; Greenland; Norway.

\section{H. occulta Bowerbank.}

H. occulta Bowerbank [in] Norman 1869a, p. 331; Id. 1874, p. 250, pl. lxxix, figs. 9-11 ; Myxilla occulta Vosmaer 1880, p. 129 ; Hymedesmia occulta Bowerbank 1882, p. 56 ; Desmacidon occultum Hanitsch 1894, p. 180 ; Hymeraphia occulta Topsent $1894 \beta$, p. 12 ; Leptosia occulta Id. $1904 a$, p. 186, pl. xv, fig. 1 ; Hymedesmia occulta Lundbeck 1910, p. 67, pl. iii, fig. 6, pl. vii, fig. 8 ; Stephens 1921, p. 37.

Distribution.-Greenland; Shetland Is.; W. and S.W. coast of Ireland ; Azores. 


\section{H. cRux (Schmidt).}

Desmacidon crux Schmidt 1875, p. 118, pl. i, figs. 10-11; Hymedesmia crux Thiele $1903 a$, p. 392 , pl. xxi, fig. 26 ; Lundbeck 1910, p. 83, pl. iii, fig. 11, pl. viii, fig. 10 ; Stephens 1921, p. 38.

Distribution.-Greenland; Norway; Faröes; S.W. coast of Ireland.

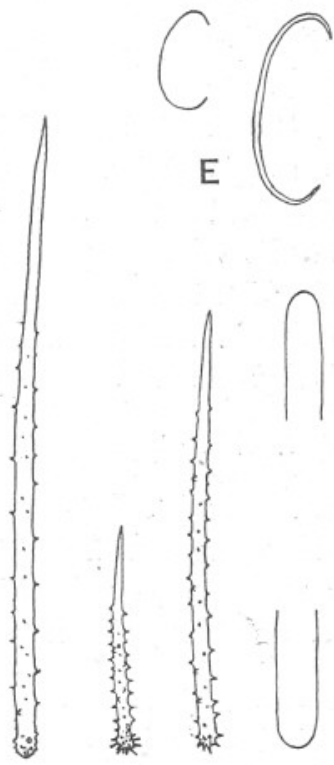

A $\quad$ B $\quad$ C $\quad$ D

Fig. 5.-Hymedesmia pilata Bowerbank. A-C, acanthostyli, showing three typical sizes, $\times 260 ; \mathrm{D}$, ends of a typical tornote, $\times 2600$; E, sigmata, $\times 650$.
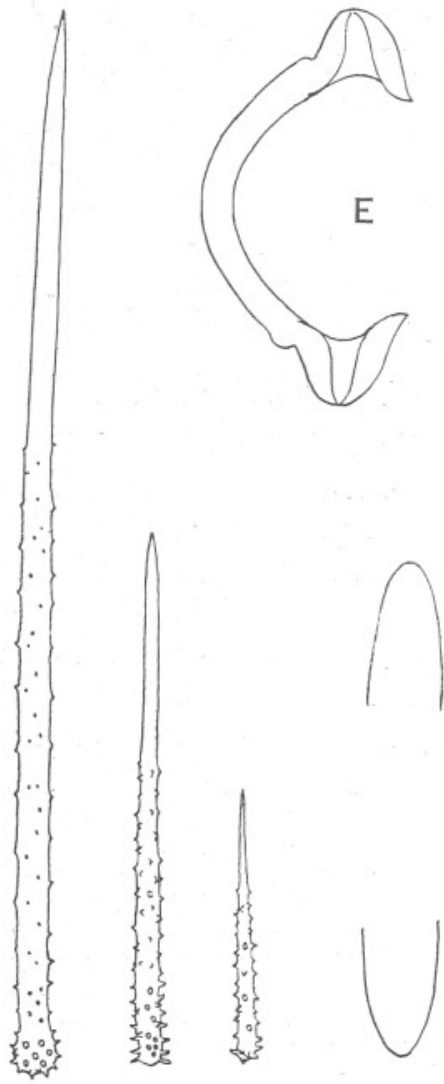

A

B

C

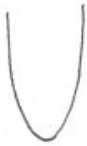

Fig. 6.-Hymedesmia peachii Bowerbank. A-C, acanthostyli of main skeleton, $\times 260 ; D$, ends of tornota, $\times 2600 ; \mathrm{E}$, isochela arcuata, $\times 1300$.

\section{H. PANSA Bowerbank.}

H. pansa Bowerbank 1882, p. 56, pl. i, figs. 1-4; H. pulchella Id. l.c., p. 61 , pl. ii, figs. $5-8$; H. pansa Stephens 1912, p. 29 ; Id. 1917, p. 11 ; Id. 1921, p. 36, pl. iv, fig. 4 . 
Remarks.-H. pulchella differs from $H$. pansa in the smaller size of its spicules only. The following are the maximum dimensions of the spicules of $H$. pulchella : large acanthostyli, $\cdot 22$ by $\cdot 006 \mathrm{~mm}$.; small acanthostyli, $\cdot 09$ by $\cdot 007 \mathrm{~mm}$. ; tornota, $\cdot 18$ by $\cdot 003 \mathrm{~mm}$.; isochelæ, $\cdot 019 \mathrm{~mm}$.

Distribution.-W. coast of Ireland; Roscoff, France (fide Stephens 1912, p. 300).

\section{H. pilata Bowerbank. (Fig. 5.)}

H. pilata Bowerbank 1882, p. 59, pl. ii, figs. 1-4.

Diagnosis.-Acanthostyli not divisible into two categories, spined for the greater part of length but smooth in distal portion, spining particularly pronounced at base, varying from $\cdot 078$ by $\cdot 009$ to $\cdot 24$ by $\cdot 008 \cdot \mathrm{mm}$., including spines; tornota extremely slender, straight, with strongylote ends, $\cdot 12$ by $\cdot 0015 \mathrm{~mm}$.; microscleres sigmata of two sorts, $\cdot 015$ and $\cdot 03 \mathrm{~mm}$. long respectively.

Distribution.-Birterbuy Bay, W. coast of Ireland.

\section{H. PEACHII Bowerbank. (Fig. 6.)}

H. peachii Bowerbank 1882, p. 64, pl. xiii, figs. 5-12.

Diagnosis.-Acanthostyli not divisible into two categories, spined for greater part of length but smooth in distal portion, spining particularly strong near base, varying from $\cdot 105$ by $\cdot 012$ to $\cdot 39$ by $\cdot 022 \mathrm{~mm}$., including spines; tornota slender, straight, with bluntly oxeote ends, $\cdot 195$ by $\cdot 003$ $\mathrm{mm}$. ; isochelæ arcuatæ, $\cdot 03 \mathrm{~mm}$. long.

Remarks.-The chelæ vary considerably in shape. The one figured probably' represents the typical form, but large numbers may be found in which the shaft is more strongly curved.

Distribution.-Wick, North Britain.

\section{H. ARMiger (Bowerbank).}

Hymeniacidon armiger Bowerbank 1882, p. 73, pl. iv, figs. 10-17.

Remarks.-The species undoubtedly belongs to Hymedesmia and Bowerbank's figures show this clearly. The reason for its having been so long ignored is probably to be found in the fact that his figures are misleading in regard to the size of the spicules. The megascleres are faithfully portrayed, the acanthostyli measuring from $\cdot 075$ to $.22 \mathrm{~mm}$. in length, and the tornota $\cdot 175$ by $\cdot 003 \mathrm{~mm}$. The microscleres are chelæ arcuatæ, chiefly remarkable for their small size, $.012 \mathrm{~mm}$. long, and form the characteristic feature of the species.

Distribution.--Roundstone Bay, Ireland. 


\section{H. KøHLERI (Topsent).}

Leptosia kohleri Topsent 1896ß, p. 284, pl. viii, figs. 7-9 ; Id. 1904a, p. 188 ; Lundbeck 1910, p. 42, pl. v, fig. 5 ; Stephens 1921, p. 34.

Distribution.-Greenland; Iceland; Faröes; W. and S.W. coasts of Ireland; Bay of Biscay; Azores.

12. H. mucronata (Topsent).

Hymeraphia mucronata Topsent $1904 a$, p. 165, pl. xiv, fig. 4 ; Hymedesmia mucronata Lundbeck 1910, p. 98, pl. x, fig. 3 ; Stephens 1921, p. 39.

Distribution.-Greenland; S.W. coast of Ireland; Azores.

13. H. MUTABILIs (Topsent).

Hymeraphia mutabilis Topsent $1904 a$, p. 166, pl. xiv, fig. 3 ; Hymedesmia mutabilis Stephens 1921, p. 38.

Distribution.-S.W. coast of Ireland; Azores.

14. H. Baculifera (Topsent).

H. baculifera Topsent $1902 \beta$, p. 354 ; Id. $1904 a$, p. 191, pl. xv, fig. 2 ; Lundbeck 1910, p. 71, pl. viii, fig. 1; Stephens 1915a, p. 440 ; Id. 1921, p. 37.

Distribution.-Greenland; Iceland; Faröes; S.W. Ireland; Mediterranean coast of Algeria; Azores; Saldanha Bay, S. Africa.

15. H. CuRvichela Lundbeck.

H. curvichela Lundbeck 1910, p. 48, pl. vi, fig. 2 ; Stephens 1921, p. 34.

Distribution.-Greenland ; S.W. coast of Ireland.

16. H. TRUNCATA Lundbeck.

H. truncata Lundbeck 1910, p. 77, pl. iii, fig. 9, pl. viii, fig. 6; Stephens 1921, p. 33.

Distribution.-Greenland; Iceland; Faröes ; S.W. coast of Ireland.

17. H. Digitata Lundbeck.

H. digitata Lundbeck 1910, p. 90, pl. iii, fig. 15, pl. ix, fig. 4 ; Stephens 1921, p. 39 .

Distribution.-Greenland; S.W. coast of Ireland.

18. H. TENUISIGMA Lundbeck.

H. tenuisigma Lundbeck 1910, p. 100, pl. x, fig. 4; Stephens 1921, p. 39 .

Distribution.-Greenland; W. coast of Ireland. 
19. H. Helge Stephens.

H. helgae Stephens 1915, p. 236 ; Id. 1921, p. 40, pl. iv, fig. 6. Distribution.-S.W. coast of Ireland.

20. H. spinosa Stephens.

H. spinosa Stephens 1916, p. 237 ; Id. 1921, p. 41, pl. iv, fig. 5.

Distribution.-S.W. coast of Ireland.

21. H. HIBERNICA Stephens.

H. hibernica Stephens 1916, p. 237 ; Id. 1921, p. 42, pl. iv, fig. 2.

Distribution.--S.W. coast of Ireland.

22. H. STEPHENSI sp. n.

Distribution.-Plymouth.

KEY TO BRITISH SPECIES OF HYMEDESMIA.

With spicules of main skeleton divided into two categories, long, usually

1 basally-spined, and short, entirely-spined, acanthostyli . . . . . . 2

With spicules of main skeleton of one sort only, but of varying size and, usually, entirely-spined . . . . . . . . . . . . . . . . 12

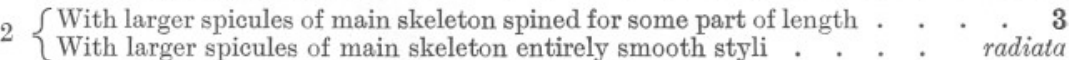

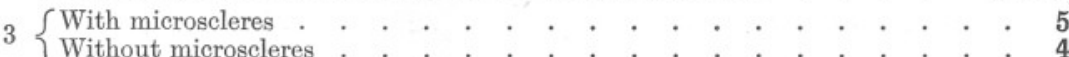

With smaller acanthostyli never less than one-third the length of larger

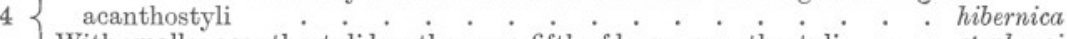
With smaller acanthostyli less than one-fifth of larger acanthostyli . . stephensi

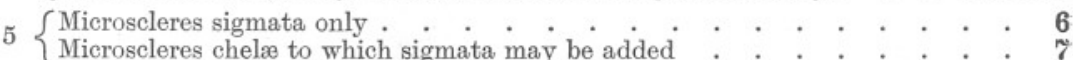

$6\{$ With microscleres less than $04 \mathrm{~mm}$. long . . . . . . . . . . pilata

With microscleres more than $04 \mathrm{~mm}$. long . . . . . . . . tenuisigma

$7\{$ Microscleres ancoræ spatuliferæ and sigmata . . . . . . . . mutabilis

Microscleres chelæ arcuatæ . . . . . . . . . . . . . . .8

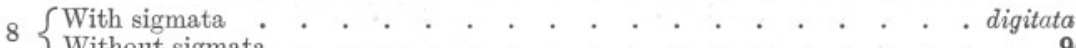

$9\left\{\begin{array}{c}\text { With larger megascleres of main skeleton spined throughout length, strongly } \\ \text { in lower, feebly along distal portion . . . . . . . . . . helgae }\end{array}\right.$

With larger megascleres of main skeleton spined in basal portion only $\quad . \quad$. 10

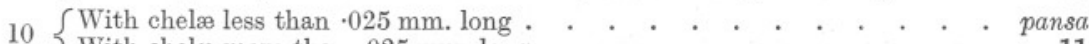

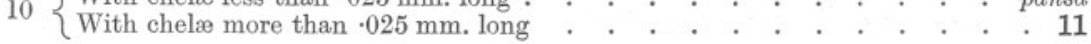

$11\left\{\begin{array}{l}\text { With oxeote tornota } \\ \text { With }\end{array} . \quad\right.$. . . . . . . . . . . . . . occulta paupertas

$12\{$ With microscleres . . . . . . . . . . . . . . . . . . . . 13

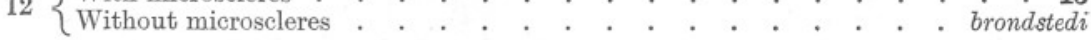

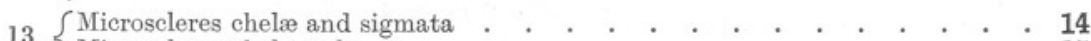

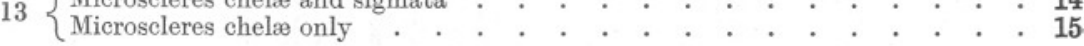

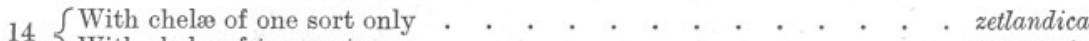

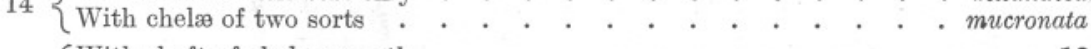

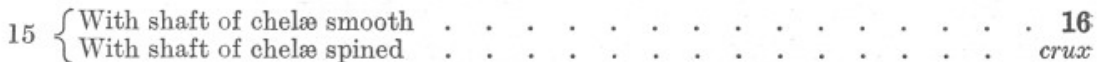


With strongylote tornota . . . . . . . . . . . . . . . 19

$16\{$ With oxeote tornota. .919

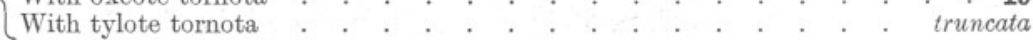

$17\{$ With polytylote tornota . . . . . . . . . . . . . 18

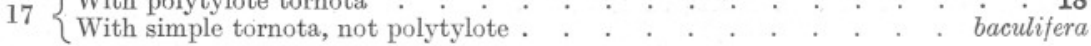

$18\{$ With shaft of chelæ strongly curved and teeth small . . . . . . curvichela

$18\{$ With chelæ of normal shape . . . . . . . . . . . . . . . . . kchleri

$19\{$ With chelæ more than $02 \mathrm{~mm}$. long . . . . . . . . . . . . 20

19 With chelæ less than $.02 \mathrm{~mm}$. long . . . . . . . . . . . armiger

$20\{$ With all acanthostyli strongly and entirely spined . . . . . . spinosa

peachii

\section{British Species of Hymedesmia now Removed to Other Genera.}

H. stellata Bowerbank 1866, p. $150=$ Timea stellata.

H. simplicima Id. 1874, p. 253, pl. Ixxx, fig. $1=$ Pseudosuberites simplicima.

The skeleton of Hymedesmia simplicima is composed of tylostyles (fig. 7) only disposed with no apparent order. They measure, on an

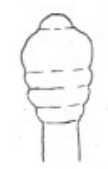

Fra. 7.-Hymedesmia simplicima Bowerbank. Head of a tylostyle, $\times 250$.

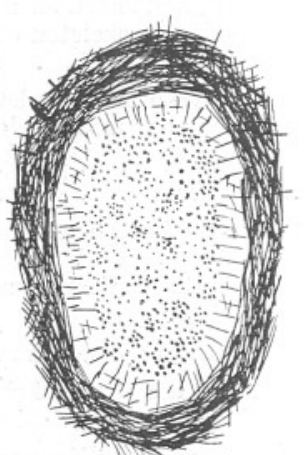

Fra. 8.-Pachaxinella subdola Bowerbank. Transverse section of a branch, showing internal axial skeleton of longitudinally-disposed spicules and outer, dermal layer. (Diagrammatic.)

average, $\cdot 6$ by $\cdot 009 \mathrm{~mm}$. The sponge itself is so small that it is difficult to be certain of its systematic position, but it is extremely possible that it is nothing more than the immediate post-fixation stage of a species of Pseudosuberites.

H. inflata Id. 1874 , p. 245 , pl. lxxix, figs. $5-8=$ Crella inflata.

The spiculation of this species consists of acanthoxea, $\cdot 096-12$ by $.006 \mathrm{~mm}$., and long, slender tornota, measuring, on an average, .5 by $\cdot 003$ $\mathrm{mm}$. The acanthoxea are for the most part slightly curved or sharply angulated and, usually, centrotylote. The tornota have oxeote ends and 
are quite straight and smooth. The species closely resembles $C$. carnosa (Topsent), but differs from it in the dimensions of the spicules, the centrotylote character of the acanthoxea, and the absence of polytylote markings on the tornota.

H. acuto-stellata Hanitsch 1894, p. 203.

The original description of this species is quite inadequate, but, so far as one may judge, it is probably an encrusting form, perhaps even the immediate post-fixation stage, of Dictyocylindrus stuposus. It is certainly not a Hymedesmia.

genus Pachaxinella gen. $\mathrm{n}$.

Genotype.-Halichondria subdola Bowerbank.

Diagnosis.-Axinellidæ of erect, branching habit; skeleton composed

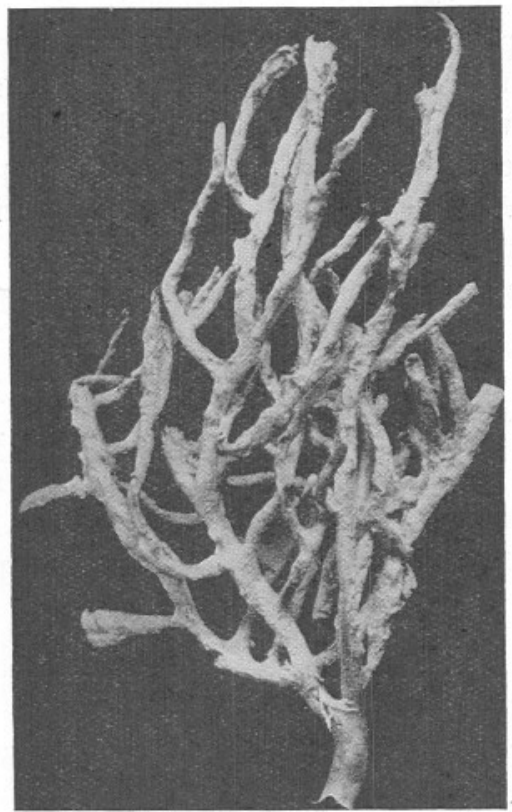

FIG. 9.-Pachaxinella subdola Bowerbank. $\times 3 / 4$.

of an axial core of loose bundles of spicules surrounded by a dense layer in which spicules are irregularly disposed, sometimes at right angles, sometimes tangential to the surface; spicules smooth styli of varying size.

Remarks.- The genus is closely allied to Homaxinella, but differs from it in the arrangement of the skeleton. The usual order of the Axinellidæ, with a dense axial skeleton and a diffuse extra-axial skeleton, is reversed. 


\section{Pachaxinella subdola (Bowerbank).}

Holotype.-B.M.-29.11.27.1.

(Figs. 8, 9.)

Halichondria subdola Bowerbank 1866, p. 247 ; Id. 1874, p. 106, pl. xliii, figs. 14-16.

Diagnosis.- Sponge erect, copiously branched, stipitate ; surface even, minutely hispid; oscules and pores not apparent; texture firm, brittle when dry; colour, in dried state, creamy-white, alive golden-yellow ; axial skeleton composed of loose bundles of spicules running longitudinally through branches, united by moderate quantity of spongin; extraaxial skeleton a dense layer of spicules, very irregularly arranged, sometimes horizontal to surface, sometimes at right angles to it, with all positions between these two; spicules smooth styli, usually straight, varying in size, $\cdot 22$ by $\cdot 003$ to $\cdot 51$ by $\cdot 006 \mathrm{~mm}$.

Remarks.-The present specimen, a complete sponge, is practically identical in all essential features with Bowerbank's fragmentary holotype.

The junction between the axial and extra-axial skeletons-is marked by a thin, almost imperceptible, zone of loose tissue supported by spicules which emerge from the axial skeleton, almost at right angles to it, and project into the extra-axial zone.

Previously known distribution.-Guernsey.

\section{LIST OF LITERATURE.}

1912. ARndT, W. Zoologische Ergebnisse der ersten Lehr-Expedition, etc. Breslau Jahresber. Ges. vaterl. Cultur, xc.

1839. Bellamy, J. C. The natural history of South Devon. Plymouth, 80 .

1834. Blannville, M. H. D. de. Manuel d'actinologie ou de zoophytologie, etc. Paris. Strasbourg, 80.

1802. Bosc, L. A. G. Histoire naturelle des vers. Paris, iii, $8^{\circ}$.

1864. Bowerbank, J. S. A monograph of the British Spongiadæ. London, Ray Soc., i, $8^{\circ}$.

1866. - A monograph of the British Spongiadæ. London, Ray Soc., ii, $8^{\circ}$.

1869a. - See Norman 1869a.

1874. — A monograph of the British Spongiadæ. London, Ray Soc., iii, $8^{\circ}$.

1882. - A monograph of the British Spongiadæ. London, Ray Soc., iv, $8^{\circ}$. 
1921. Dendy, A. Report on the Sigmatotetraxonida collected by H.M.S. Sealark in the Indian Ocean. Trans. Linn. Soc. Zool., London, xviii.

1755. Ellis, J. An essay towards the natural history of Corallines, etc. London, $4^{\circ}$.

1828. Fleming, J. A history of British animals, etc. EdinburghLondon.

1791. Gmelin, - . (in) Linnæus, C. Systema naturæ. Tom. i. Pars. 6. Editio decima tertia, Lipsiæ.

1825. Grant, R. E. Observations and experiments on the structure and functions of the sponge. Edin. Phil. Journ., xiii.

1826a. - Observations and experiments on the structure and functions of the sponge. Edin. Phil. Journ., xiv.

$1826 \xi$. Observations on the structure of some siliceous sponges. Edin. New Phil. Journ., i.

$1826 \eta$. Observations on the structure and functions of the sponge. Edin. New Phil. Journ., ii.

1867. Gray, J. E. Notes on the arrangement of sponges, etc. Proc. Zool. Soc., London.

1821. Gray, S. F. A natural arrangement of British plants. London, i, 80 .

1894. HanitsCh, R. Revision of the generic nomenclature and classification in Bowerbank's "British Spongiadæ." Trans. Liverpool Biol. Soc., viii.

1842. Johnston, G. A history of British sponges and lithophytes. Edinburgh, London, Dublin, $8^{\circ}$.

1816. Lamarck, J. B. P. A. DE Monet. Histoire naturelle des animaux sans vertèbres, etc. Tom. ii. Paris.

1916. Lamouroux, J. V. F. Histoire des polypiers coralligènes flexibles, etc. Caen, F. Poisson, $8^{\circ}$.

*1887a. Levinsen, G. M. R. Un coup d'œil sur la faune de la Mer Kara. Dijmphna-Toglets Zool.-Bot. Ualytte ved. Chr. Fr. Lütken Kjøbenhavn, pp. 512-513.

1909. Lundbeck, W. The Porifera of East Greenland. Meddel. om Grønland, xxix.

1910. — Porifera. (Part iii.) Desmacidonidæ (Pars.). Danish Ingolf-Exped., vi.

* Omitted from Vosmaer's Bibliography. 
1818. Montagu, G. An essay on sponges, etc. Mem. Werner. Soc., ii.

1776. MüLler, O. F. Zoologiæ Danicæ prodromus, etc. Havniæ, 40.

1789. Z Zoologica danica, vol. iii. Havniæ. Fol.

1869a. Norman, A. M. Shetland final dredging report. Rep. 38th Meeting Brit. Assoc.

1869. Parfitt, E. On the marine and freshwater sponges of Devonshire. Trans. Devonshire Assoc.

1887. Ridley, S. O. and Dendy, A. Report on the Monaxonida collected by H.M.S. Challenger, etc. Rep. Scient. Res. Challenger Zool., xx.

1870. Sснмгтт, 0. Grundzüge einer Spongien-Fauna des atlantischen Gebietes. Leipzig. Fol.

1875. Spongien bearbeitet. Jahresber. Comm. Unters. d. Meere, ii, iii.

1912. Stephens, J. Clare Island Survey. Part 59. Proc. R. Irish Acad., xxxi.

1915. Sponges of the coast of Ireland. I. The Triaxonida and part of the Tetraxonida. Dublin Fish., Ireland. Sci. Invest., No. 4.

1915a. - Atlantic sponges collected by the Scottish National Antarctic expedition. Trans. Roy. Soc., Edinburgh, xl.

1916. — Preliminary notice of some Irish sponges, etc. Ann. Mag. Nat. Hist., London, xvii.

1917. Sponges collected by the dredging expeditions of the Royal Irish Academy, etc. Dublin Proc. R. Irish Acad., xxxiv, Sect. B.

1921. - Sponges of the coasts of Ireland. II. The Tetraxonida (concluded). Dublin Fish., Ireland. Sci. Invest., No. 2.

1903a. ThIELe, J. Beschreibung einiger unzureichend bekannten monaxonen Spongien. Arch. Naturgesch., lxix.

1888. Topsent, É. Contribution à l'étude des Clionides. Arch. Zool. Éxpér. (2) v bis. suppl.

1890. E Éponges de la Manche. Mém. Soc. Zool., Fr., iii.

1891. Essai sur la faune des spongiaires de Roscoff. Arch. Zool. Exp. (2) ix.

1892. Contribution a l'étude des Spongiaires de l'Atlantique Nord. Rés. Campagnes scientifiques accomplis sur son Yacht par Albert I ${ }^{\text {er }}$ Prince Souverain de Monaco. Fasc. ii. 
1894. - Application de la taxonomie actuelle à une collection de spongiaires du Banc de Campêche, etc. Mém. Soc. Zool., Fr., vii.

1894a. Campagne de la Melita, 1892. Éponges du Golfe de Gabès. Mém. Soc. Zool., Fr., vii.

$1894 \beta$. E Étude sur la faune des Spongiaires du Pas de Calais, etc. Rev. Biol. Nord de la France, vii.

1896 3. — Éponges. [Kœhler] Rés. Sci. Campagne "Caudan," Lyon.

$1902 \beta$. - Considérations sur la faune des spongiaires des Côtes d'Algérie. Éponges de la Calle. Arch. Zool. Expér., (3) ix.

1904a. Spongiaires des Açores. Rés. Camp. Sci. Alb. Monaco, Fasc. 25.

1911a. - Sur les affinités des Halichondria et la classification des Halichondrines d'après leurs formes larvaires. Arch. Zool. Expér., (5) vii.

1913. Spongiaires provenant des campagnes scientifiques de la Princesse Alice dans les Mers du Nord. Rés. Camp. Sc. Monaco, xlv,

$1920 \beta$. - Spongiaires du Musée zoologique de Strasbourg. Monaxonides. Monaco Bull. Inst. océan. No. 381.

1806. Turton, W. A general system of nature, etc. Vol. iv, London.

1880. Vosmar, G. C. J. The sponges of the Leyden Museum, i. The family of the Desmacidinæ. Notes Leyden Museum, ii.

(The references to literature published prior to 1914 are quoted from Vosmaer's Bibliography.) 
